\title{
Kompetence k učení a možnosti jejího rozvíjení a hodnocení: vymezení pojmu a přehled současných př́ístupů ${ }^{1}$
}

\author{
Veronika Lokajíčková \\ Masarykova univerzita, Pedagogická fakulta, Institut výzkumu školního vzdělávání
}

Redakci zasláno 22. 4. 2013 / upravená verze obdržena 20. 6. 2013 / k uveřejnění přijato 21. 6.2013

\begin{abstract}
Abstrakt: Přehledová studie zpřístupňuje poznatky o kompetenci k učení a možnostech jejího rozvíjení ve výuce. Studie je rozvržena do dvou částí. První část se zabývá vymezením kompetence $\mathrm{k}$ učení $\mathrm{v}$ návaznosti na koncept (klíčových) kompetencí. S oporou o vybrané autory je kompetence k učení strukturována do dílčích dimenzí - (sub)dimenzí a je tak upozorněno na problém jejího pojetí jako multidimenzionálního konstruktu. Dále je poukázáno na zařazení jednotlivých dimenzí a (sub)dimenzí u vybraných autorů, což přináší další komplikace spojené s tímto konstruktem. $\mathrm{U}$ autorů jsou identifikovány tři přístupy $\mathrm{k}$ vymezení kompetence $\mathrm{k}$ učení prostřednictvím: (1) kvalit - charakteristik, (2) komponent - složek a (3) propojením kvalit a komponent (kombinovaný př́stup). $V$ druhé části studie jsou představeny čtyři domácí př́ístupy umožňující rozvíjet kompetenci k učení ve výuce. První dva představené př́ístupy (Výzkumného ústavu pedagogického) nahlíží na kompetenci k učení prostřednictvím „širší perspektivy (makroměřítko). Další dva přístupy (Chvála a Kasíkové a Institutu výzkumu školního vzdělávání) nahlíží na kompetenci k učení více zaostř̌eně (mikroměřítko) a umožňují i její hodnocení.
\end{abstract}

Klíčová slova: kompetence k učení, učení se učit, kompetence, klíčové kompetence, rozvíjení kompetence, kvalita výuky, hodnocení

Kompetence $k$ učení je konceptem novým, který se v českém kurikulu objevil relativně nedávno a jeho etablování je mj. spojeno se zaváděním rámcových vzdělávacích programů (dále jen RVP) do školní praxe. Schopnost učit se by si měl každý jedinec postupně osvojit tak, aby obstál nejen v průběhu školní docházky, ale i v běžném životě. I proto se rozvíjení kompetence $k$ učení stalo jedním z cílů českého školství. Tato kompetence není v učebním procesu

\footnotetext{
1 Vznik této studie byl podpořen Stipendijním fondem PdF MU (Podpora talentovaných prezenčních doktorandů) a projektem GA ČR P407/11/0262 Kvalita kurikula a výuky v oborech školního vzdělávání.
} 
konceptem izolovaným; je úzce spjata s „novou” kulturou vyučování a učení, která nachází svůj teoretický fundament v teoriích pedagogického a didaktického konstruktivismu. Problematika rozvíjení i hodnocení (klíčových) kompetencí zároveň patří mezi nejnáročnější a nejvíce problematické kurikulární činnosti. Komplikace však přináší jak vágní vymezení kompetence k učení, tak i její operacionalizace formou multidimenzionálního konstruktu, který je pro učitele ve výuce obtížně uchopitelný. Pokud je naším záměrem kompetenci $k$ učení v zájmu kvality výuky rozvíjet, je nezbytné mít $\mathrm{k}$ dispozici př́istupy, které ji umožní uchopit pro potřeby praxe. Cílem našeho textu je teoreticky uchopit kompetenci k učení jako multidimenzionální konstrukt a zároveň představit ty př́stupy, které mohou být z hlediska rozvíjení kompetence k učení ve výuce užitečné (pro učitele i výzkumníky).

\section{1 (Klíčové) kompetence}

Kompetence (angl. competence, něm. Kompetenz) patř́ mezi jeden ze (staro)nových pojmů a trendů „nové“ kultury vyučování a učení, se kterými pracují na kurikulární úrovni kromě České republiky i další nejen evropské země. Tento koncept, převzatý $\mathrm{z}$ odborného (profesního) vzdělávání, byl do oblasti pedagogicko-psychologické diagnostiky zaveden jako protiváha vůči generalizovaným, kontextově nezávislým kognitivním výkonovým konstruktům, které jsou typické pro výzkum a diagnostiku inteligence. Klieme et al. (2010, s. 105) upřesňují, že „zatímco ve výzkumu inteligence jsou zkoumány kognitivní výkonové konstrukty, které lze zobecnit na široké spektrum situací, kompetenční konstrukty se vztahují na specifické oblasti požadavků. Otázka ,kompetentní pro co je nezbytnou součástí každé definice pojmu kompetence“.

Klíčovou charakteristikou pojmu kompetence v oblasti pedagogicko-psychologické diagnostiky je podle Kliemeho et al. (2010, s. 106) prvotní silnější vztah ke "skutečnému životu“ - vyjádřený např. souhrnem požadavků profesních kontextů. Klieme et al. (2010, s. 107) kompetence vymezují jako kontextově specifické kognitivní výkonové dispozice, které se funkčně vztahují na situace a požadavky v určité doméně (srov. také Weinert, 2001, s. 57). Tyto dispozice lze podle Kliemeho et al. (2010) charakterizovat jako znalosti, dovednosti či rutiny (návyky). Perrenoud (1997 in Skalková, 2007, s. 13) kompetence definuje jako schopnost účinně jednat $v$ určitém typu situací (složitých, rozmanitých a nepředvídatelných), schopnost založenou na znalostech, která se však neomezuje jen na ně (srov. Fredriksson \& Hoskins, 2007, 
s. 129; Klieme et al., 2010, s. 108). ${ }^{2}$ Klieme et al. (2010, s. 108) upozorňují, že v uvedeném vymezení kompetencí má kritický význam právě definování kontextu - oblasti situací a požadavků, na které se určitý specifický kompetenční konstrukt vztahuje. Z této kontextové vázanosti kompetencí podle Kliemeho et al. (2010, s. 107) vyplývá, že kompetence mohou, resp. musí být získány učením: „Z vazby kompetence na specifické situace a požadavky je zřejmé, že získávání kompetencí předpokládá získávání zkušeností v odpovídajících situacích, resp. úlohách" (srov. Knecht et al., 2010, s. 49).

Vedle kompetencí se navíc objevují i v pedagogickém diskurzu kompetence klíčové. Klíčové kompetence tzn. „základní” či „podstatné” (angl. key competencies ${ }^{3}$, něm. Schlüsselkompetenzen) jsou v oficiálních dokumentech (české) vzdělávací politiky pokládány za stěžejní cíle vzdělávání a jsou spojovány s inovací encyklopedického vzdělávání ${ }^{4}$ Koncept klíčových kompetencí popsal již v roce 1974 Mertens (srov. Belz \& Siegriest, 2001, s. 28) a označil tak ty kompetence, které pomáhají vyrovnávat se se skutečností a zvládat nároky flexibilního světa práce. Jsou obsahově neutrální, ale jejich zprostředkování je vázáno na konkrétní obsah (Belz \& Siegriest, 2001). Podle Kliemeho et al. (2010, s. 116) ale nemusí být u klíčových kompetencí (popř. nadoborových ${ }^{5}$ ) podmínka závislosti na kontextu nutně splněna nebo je velmi „velkorysá". Veteška a Tureckiová $(2008$, s. 63) vysvětlují rozdíl mezi kompetencemi a klíčovými kompetencemi takto:

Kompetence jsou definovány jako kombinace znalostí, dovedností a postojů odpovídajících určitému kontextu. Klíčovými kompetencemi jsou ty, jež všichni potřebují ke svému osobnímu naplnění a rozvoji, aktivnímu občanství, sociálnímu začlenění a pro pracovní život.

2 Kompetenci můžeme oproti schopnosti vymezit jako komplexnější a zásadně kontextově podmíněnou (Veteška \& Tureckiová, 2008, s. 31).

3 Key competencies jsou označením nejčastějším, ale můžeme se setkat také s termíny core competencies (jádrové kompetence), key qualifications (klíčové kvalifikace), core skills (jádrové dovednosti) (Weinert, 2001) nebo také key skills (klíčové dovednosti), thinking skills (dovednosti myšlení) či functional skills (funkční dovednosti) (Kocourková \& Pastorová, 2011).

4 S určitým zjednodušením lze říci, že encyklopedické vzdělávání je podle autorů evropských kurikulárních dokumentů, s přihlédnutím na aktuální pedagogický diskurs, považováno za hodné přehodnocení. Moderní vzdělávání by mělo vést ke snadnějšímu uplatnění jedinců jak na pracovním trhu, tak i v praktickém životě. Má vést žáky např. $\mathrm{k}$ tomu, aby se naučili získané poznatky aplikovat $\mathrm{v}$ praxi.

5 Vedle kompetencí klíčových můžeme vymezit i kompetence mezioborové (angl. crosscurricular, něm. fächerübergreifend). V českém překladu se můžeme setkat i s termíny jako obor přesahující, nadoborová nebo kroskurikuálrní kompetence (Knecht et al., 2010). 
Jako klíčové je tedy možné označit takové kompetence, které lze hodnotit kvalitativně výše než kompetence ostatní (srov. Belz \& Siegriest, 2001, s. 28; Hoskins \& Fredriksson, 2008, s. 11). Vymezení tohoto konceptu však přináší určité komplikace - jednak neexistuje jedna obecně akceptovaná definice kompetencí a neexistuje ani sjednocující teorie, která by kompetence legitimizovala jako relativně ustálený teoretický konstrukt (Knecht et al., 2010, s. 4; Weinert, 2001, s. 45-46). Vágnost ve vymezení přináší značné problémy učitelům v souvislosti s výukou orientovanou na kompetence (Waeytens et al., 2002, s. 306). Mimoto Kaščák a Pupala (2009) zdůrazňují, že kompetence nejsou produktem pedagogického myšlení, ale mají politický původ. Někteří teoretici vzdělávání je podle citovaných autorů mylně přijímají jako klíčové pojmy moderní teorie vzdělávání. Krámský (2006) z pohledu filosofie výchovy označuje v určitém kontextu tento pojem za nenáležitý a polemizuje, zda cílové zaměření kompetencí neslibuje něco, co není možné v praxi splnit. Z pohledu filosofie výchovy se kompetencemi obvykle rozumí „uzpůsobilost či obratnost k nějaké činnosti, vztahům, rozhodnutí, spravedlivým soudům, ale jde též o zaujímání morálních postojů“ (Krámský, 2006, s. 112).

Výše uvedené vyústilo ve fakt, že klíčové kompetence nebyly pedagogy přijaty „idylicky” a bez námitek. Výhrady ke kompetencím najdeme u výzkumníků operujících jak na poli obecné, tak i oborové didaktiky (Janík et al., 2010b; Kaščák \& Pupala, 2009; Klieme et al., 2010; Řezníčková, 2006; Štech, 2009 aj.). Janík et al. (2011, s. 19) shrnují hlavní problémy s výukou orientovanou na kompetence do tří bodů: (a) učitelé se soustředí nikoliv na cíle, ale na utváření obsahu výuky a na žákovu práci s obsahem; (b) náročnost didaktického zobecnění obsahu a transferu poznatků a (c) neujasněnost pojmu (klíčové) kompetence v teorii i praxi. Ke koncepční neujasněnosti problematiky přispívá také používání pojmu kompetence $\mathrm{v}$ českém jazyce, který na rozdíl od angličtiny neumožňuje rozlišit pojem competence (užíván v holistickém významu) od competency, tj. dílčích složek ve vztahu k výkonu (např. kompetence jako symbolická i grafická vyjádření informací různého typu).

Plurálový tvar competencies - odvozený od singuláru competency - se vztahuje k jednotlivým dílčím složkám situovaných „dovnitř” celostně pojaté kompetence. Český pojmový aparát tento rozdíl nereflektuje - četné nejasnosti pramení z toho, že jednou je termín kompetence používán v singuláru jako pojem obecný a nadřazený, jindy je používán v plurálu pro označení různých dílčích složek (Knecht et al., 2010, s. 40). 


\section{Kompetence k učení}

Klíčových kompetencí je napříč dokumenty vzdělávací (kurikulární) politiky z různých zemí vymezena celá řada a jejich konkrétní určení pak vychází z priorit ve vzdělávání a ze sociálních i kulturních zvyklostí dané země. Rámcový vzdělávací program pro základní vzdělávání (dále jen RVP ZV) vymezuje šest klíčových kompetencí: kompetence $k$ učení, ${ }^{6}$ kompetence $\mathrm{k}$ řešení problémů, kompetence komunikativní, kompetence sociální a personální, kompetence občanská a kompetence pracovní (srov. Rámcový vzdělávací ..., 2007, s. 14-17).

Kompetence $k$ učení (angl. learning competencies, něm. Lernkompetenz) patří mezi ty důležitější, které bychom si měli v průběhu života a především školní docházky osvojit, protože potřeba „něčemu se naučit” provází každého jednotlivce celým životem. Přestože tento koncept vstoupil do diskurzu o školním kurikulu relativně nedávno, připravenost žáka k učení však není $\mathrm{v}$ českém pedagogickém výzkumu problematikou novou. $\mathrm{V}$ minulosti byla zkoumána s využitím konstruktů jako: kognitivní svébytnost, autoregulace, autonomní učení, pojetí učiva, školní zdatnost, školní úspěšnost, způsobilost učit se, docilita, subjektivní smysl učiva nebo vnímaná instrumentalita učiva pro budoucí cíle (Chvál, Kasíková, \& Valenta, 2012, s. 11).

Je namístě alespoň vybrané z těchto výše uvedených konstruktů stručně specifikovat. Jak je patrné z následujících definic, vymezení těchto konstruktů se místy překrývá, a proto mnohdy není jednoduché je od sebe oddělit. Kognitivní svébytnost, pojem v pedagogické psychologii spíše ojedinělý a doplňující, charakterizuje autonomii a nezávislost poznání. Tento konstrukt je utvářený prostřednictvím metakognice ${ }^{7}$ a autoregulace (Krykorková, 2008, s. 141,149). Podle Mareše (1998, s. 173) je autoregulace učení ${ }^{8}$ „taková úroveň učení, kdy se člověk (žák, student) stává aktivním aktérem svého vlastního procesu učení jak po stránce činnostní a motivační, tak metakognitivní“.

6 Kurikulární dokumenty zemí Commonwealthu mnohdy nepracují přímo s konceptem kompetence $k$ učení. Velká Británie pracuje s konceptem zdokonalování vlastního učení a výkonu (improving own learning and performance) nebo s dovednostmi k myšlení a učení (learning and thinking skills). Na Novém Zélandu jsou myšlenky kompetence $k$ učení obsahem jiných kompetencí - klíčové kompetence k myšlení a klíčové kompetence užívání jazyka, symbolů a textů. V Irsku se předpokládá, že s rozvojem jiných pěti klíčových dovedností rostou zároveň znalosti žáků o učení i jejich schopnost učit se učit (Kocourková \& Pastorová, 2011).

7 Metakognicí v užším pojetí rozumíme „určitou formu poznání, která má nadhled nad naším poznáním, učením a myšlením“ (Krykorková \& Chvál, 2001, s. 188). Dle Mareše (1998, s. 169) můžeme metakognici označit jako „poznávání na druhou”.

8 Podrobněji se u nás autoregulaci učení věnuje Hrbáčková et al. (2010) nebo Mareš (1998). 
Metakognice je tedy součástí autoregulace. A svým vymezením je kognitivní svébytnosti blízké také autonomní učení. Podle Krykorkové (2008, s. 141) se dva výše zmíněné pojmy liší v dílčích charakteristikách, které postrádají soustavné vymezení, popř́ípadě je pojem autonomie spojování se samostatností a převzetím odpovědnosti za výsledky učebního procesu.

Termín pojetí učiva vymezili Mareš a Ouhrabka (2007, s. 419) a charakterizují ho jako „souhrn žákových subjektivních poznatků, představ, přesvědčení, emocí a očekávání týkající se školního učiva“.

Blízké jsou si pojmy školní zdatnost a školní úspěšnost. Hrabal st. a Hrabal ml. (2002, s. 45-46) je diferencují:

školní zdatnost je označením souboru dispozic, které žákovi umožňují plnit požadavky školy a realizovat tak více či méně úspěšně roli žáka ve vyučování. Školní úspěšnost je sociálním hodnocením toho, jak žákova činnost odpovídá požadavkům školy. Zdatnost je komplexem dispozic, které úspěšnost podmiňují.

Samotná kompetence $k$ učení spadá do konceptu celoživotního učení, které umožňuje co největší využití lidského potenciálu, což je vnímáno jako nezbytný proces vedoucí k úspěšnému uplatnění se na trhu práce. Za základ celoživotního učení je považováno kvalitní základní vzdělání, které by mělo „naučit jedince učit se” a mít k učení pozitivní postoj (Veteška \& Tureckiová, 2008, s. 20).

\subsection{Vymezení konceptu kompetence $k$ učení}

Obecně můžeme říci, že vymezení kompetence $k$ učení vychází z aktuálního přístupu k učení, který se váže na kontext a zahrnuje nejen „vědět co” (know what), ale především „vědět jak” (know how) a také „vědět proč” (know why) (Crick, 2007, s. 136).

Stringherová (2006 in Hoskins \& Fredriksson, 2008, s. 16) analyzovala vymezení pojmu schopnost učit se z různých zdrojů a našla celkem 40 různých definic. Zjistila, že současné chápání schopnosti učit se je spojeno s pojmy jako je metakognice, sociokonstruktivismus, socio-kognitivní a sociálně-historické přístupy, celoživotní vzdělávání a se studiemi v oblasti hodnocení (assessment studies). Poukázala tak na složitost tohoto konceptu a na různé přístupy k jeho chápání. RVP ZV vymezuje kompetenci $k$ učení prostřednictvím činností, které by měl žák na konci základního vzdělávání zvládat (např. vybírá a využívá pro efektivní učení vhodné způsoby, metody a strategie; plánuje, 
organizuje a řídí vlastní učení; vyhledává a třídí informace..., podrob. Rámcový vzdělávací..., 2007, s. 14).

$\mathrm{V}$ odborné literatuře psané anglicky se setkáváme s pojmem learning to learn, který však vždy nelze považovat za synonymní s learning competencies. Learning competencies (kompetence $k$ učení) chápeme jako dispozici ke zvládání situací k učení, kdežto learning to learn (učení se učit či metaučení) vnímáme jako proces, který učení provází. Přikláníme se tedy k pojetí Mareše, který koncept learning to learn v českém jazyce ztotožňuje s učením se učit či metaučením (Mareš, 1998, s. 142; srov. Moreno \& Martín, 2007, s. 184). S oporou o Hautamäkiho (2002 in Fredriksson \& Hoskins, 2007) learning to learn vnímáme jako nadřazené learning competencies. Někteří autoři mnohdy nejspíše tento rozdíl nereflektují a kompetenci $k$ učení ztotožňují s learning to learn, přestože patrně nemají na mysli onen proces, který učení provází a k učení vede (např. Chvál, Kasíková, \& Valenta, 2012; Mesárošová et al., 2012). Rozdíl v obou pojmech je patrný v níže uvedených definicích, kdy ta první definuje learning to learn a druhá learning competencies. Navíc je do roviny kompetence $k$ učení stavěno i celoživotní učení (srov. Trier, 2001; Stringher, 2006; Fredriksson \& Hoskins, 2007).

Evropský rámec vytvořený Evropským parlamentem a Radou EU v roce 2006 vymezuje kompetenci k učení v protnutí psychologického a socio-kulturálního paradigmatu jako

schopnost učit se, $v$ procesu učení vytrvávat, zorganizovat si učení a efektivně hospodařit se svým časem a s informacemi, a to jak samostatně, tak i v rámci skupin. Tato kompetence zahrnuje povědomí o vlastních postupech učení a vlastních potřebách, schopnostmi rozpoznávat dostupné možnosti a překonávat překážky za účelem úspěšnosti procesu učení. To znamená získávat, zpracovávat a osvojovat si nové znalosti a dovednosti, vyhledávat rady a využívat je. (Education Council, 2006; přeloženo Veteška \& Tureckiová, 2008, s. 148-149)

Rozhodujícími aspekty této kompetence podle této definice jsou motivace a sebedůvěra. Chvál, Kasíková a Valenta kompetenci k učení chápou jako dispozici ke zvládání situací učení:

je charakterizována porozuměním procesům učení včetně jeho reflexe, dovednostmi a schopnosti vytvářet podmínky pro vlastní učení, hledat a nacházet nástroje k podpoře vlastního učení. (2012, s. 12) 
V situacích učení, jejichž prostřednictvím je kompetence k učení rozvíjena, potom spočívá kvalita výuky. Krykorková a Volf (2010, s. 157) pracují s konceptem úkolová situace, která je úkolem,

ve kterém je obsažen požadavek na žáka, je určitým způsobem prezentován zpracován, organizován, nachází se na určitém stupni náročnosti, je v něm obsažena motivace i regulace kognitivní činnosti.

\subsection{Dimenze kompetence k učení/učení se učit}

Kompetenci $k$ učení můžeme strukturovat s oporou o Triera (2001), Bonneta et al. (2006 in Fredriksson \& Hoskins, 2007) a dalších autorů do dílčích dimenzí. Jak je patrné z Tabulky 1,2 a 3, u autorů se můžeme setkat i s vymezením složek (Mareš, 1998; Mesárošová et al., 2012), oblastí (Moreno \& Martín, 2007) či hlavními prvky (Hautamäki, 2002). V následujícím textu představíme podrobnější strukturování kompetence $\mathrm{k}$ učení do dílčích dimenzí vybranými autory (řadíme chronologicky), následně je rozebereme a předložíme pokus o jejich utřídění.

Mareš (1998) vymezuje šest dílčích složek učení se učit: (1) generickou, (2) kontextově specifickou, (3) kognitivní, (4) regulační, (5) motivační a (6) volní. Trier (2001) vymezuje tři dimenze kompetence $k$ učení a celoživotního učení: (1) technickou / metodologickou (technical / methodological), (2) strategickou (strategic) a (3) motivační (motivational).

Hautamäki et al. (2002 in Fredriksson \& Hoskins, 2007) vydělují tři hlavní prvky (major elements), které se dále členído domén (domain): (1) kompetence $k$ učení - doména učení (learning domain); oblast uvažování (reasoning domain); ř́zení učení (management of learning); afektivní autoregulace (affective self-regulation), (2) přesvědčení vztažená k Já (self-related beliefs) učební motivace (learning motivation); rrízení jednání (action-control beliefs); akademické sebepojetí ve škole (academic selves at school); přijetí úkolu (assignment / task acceptance); autoevaluace (self-evaluation); perspektivní orientace (future orientation) a (3) kontextově vázaná přesvědčení (contextrelated beliefs) - společenské rámce (societal frames); vnímaná podpora pro učení a studium (perceived support for learning and studying).

Education Council (2006) strukturuje kompetenci k učení prostřednictvím dvou dimenzí (dimension): (1) kognitivní - schopnost získat znalosti, zpracovat a asimilovat nové znalosti (capacity to gain, process and assimilate new 
knowledge); žákovské plánování vlastního učení (students organizing their own learning) a (2) afektivní - související se sociálními dovednostmi - učební vztahy (learning relationships); motivace (motivation); sebedůvěra (confidence); strategie učení (learning strategies); schopnost překonávat překážky (the ability to overcome obstacles).

Bonnet et al. (2006 in Fredriksson \& Hoskins, 2007) strukturují kompetenci k učení do dvou dimenzí: (1) kognitivní - identifikace propozic (identifying a proposition); užití pravidel (using rules); testování pravidel a propozic (testing rules and propositions); využívání mentálních nástrojů (using mental tools) a (2) afektivní - učební motivace (learning motivation); učební strategie a orientace na změnu (learning strategies and orientation toward change); akademické sebepojetí a sebedůvěra (academic self-concept and self-esteem); učební prostředí (learning environment) a vnímaná podpora ze strany významných osob (perceived support from significant other) a učební vztah (learning relationship). Morenová a Martínová (2007) vymezují oblasti (areas): (1) kognitivní - učit se přemýšlet (learning to think); metakognice (metacognition) a (2) emocionální - učební strategie (learning strategies); důvěra ve vlastní schopnosti (self-efficacy); motivace (motivation). Totožně jako Bonnet et al. (2006) strukturují kompetenci k učení i Hoskinsová a Fredriksson (2008) a Kupiainen et al. (2008), pouze u afektivní dimenze nezahrnují vnímanou podporu a navíc vyčleňují kromě dimenze (1) kognitivní a (2) afektivní i dimenzi (3) metakognitivní - řešení problému (problem solving); (meta)kognitivní monitorování úkolu (metacognitive monitoring tasks); metakognitivní přesnost (metacognitive accuracy); metakognitivní sebedůvěra (metacognitive confidence).

Mesárošová et al. (2012) vymezují pět složek kompetence k učení: (1) kognitivní - znalosti procesů učení a pamětové postupy; metakognitivní strategie; učební styly a př́ístupy k učení; učební strategie, (2) emocionální - citová zaangažovanost v učení; oddanost procesu učení, (3) motivační - kognitivní a výkonová motivace učení, (4) seberegulační a sebepoznávací a (5) postojová a hodnotová.

Při bližší analýze dimenzí jsou patrné tři př́istupy, jejichž prostřednictvím výše zmínění autoři dimenze kompetence $k$ učení vymezují:

(1) prostřednictvím kvalit, tj. charakteristik kompetence $k$ učení vyjádřených adjektivy (Mareš, 1998; Trier, 2001; tabulka 1). 
(2) prostřednictvím komponent, tj. složek žákovské disponovanosti k učení (Hautamäki et al., 2002; tabulka 2).

(3) prostřednictvím kvalit i komponent - kombinovaný9 (Bonnet et al., 2006; Education Council, 2006; Hoskins \& Fredriksson, 2008; Kupiainen et al., 2008; Mesárošové et al., 2012; tabulka 3). ${ }^{10}$

Tabulka 1

Dimenze kompetence $k$ učení vymezené prostřednictvím kvalit

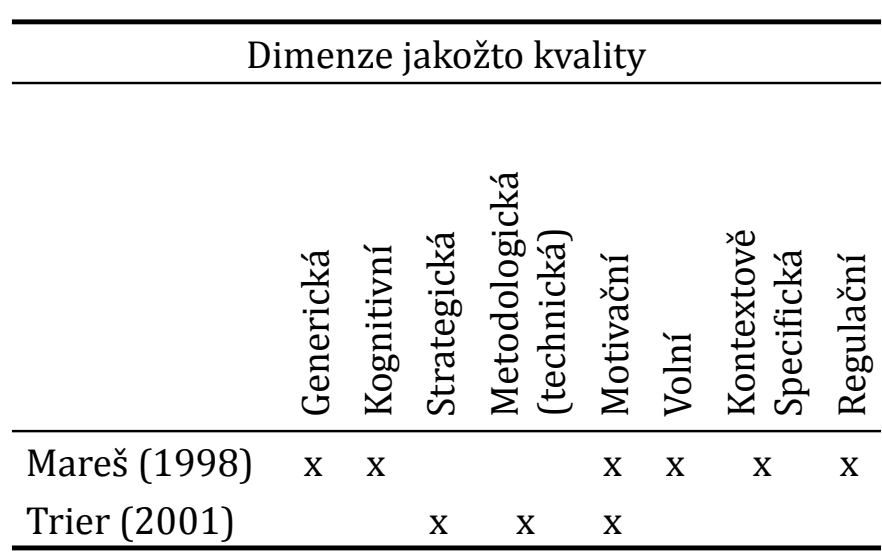

Tabulka 2

Dimenze kompetence $k$ učení vymezené prostřednictvím komponent

\begin{tabular}{|c|c|c|c|c|c|c|c|c|c|c|c|c|}
\hline $\begin{array}{l}\text { Dimenze jakožto } \\
\text { komponenty }\end{array}$ & \multicolumn{4}{|c|}{$\begin{array}{c}\text { Kompetence } \\
\text { k učení }\end{array}$} & \multicolumn{6}{|c|}{$\begin{array}{l}\text { Přesvědčení vztažená } \\
\text { k já }\end{array}$} & \multicolumn{2}{|c|}{$\begin{array}{c}\text { Kontextově vázaná } \\
\text { přesvědčení }\end{array}$} \\
\hline (Sub)dimenze & 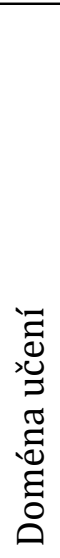 & 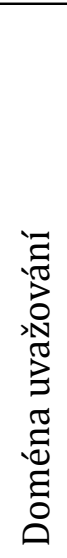 & 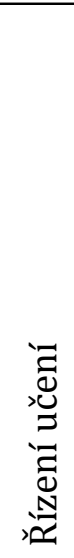 & 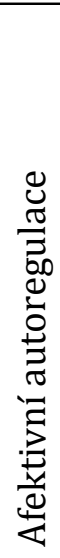 & 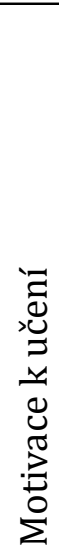 & 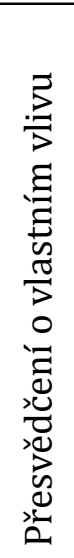 & 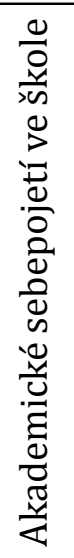 & 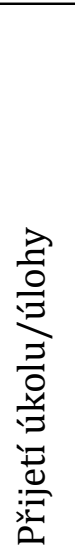 & 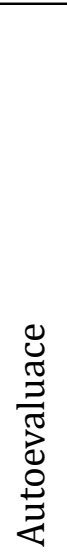 & 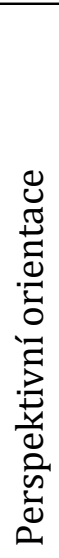 & 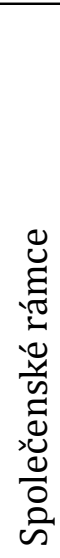 & 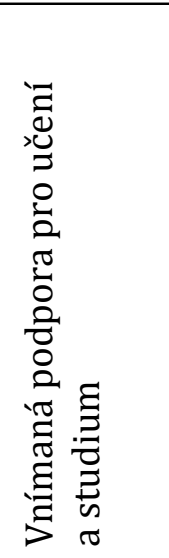 \\
\hline Hautamäki et al. (2002) & $\mathrm{x}$ & $\mathrm{x}$ & $\mathrm{x}$ & $\mathrm{x}$ & $\mathrm{x}$ & $\mathrm{x}$ & $\mathrm{x}$ & $\mathrm{x}$ & $\mathrm{x}$ & $\mathrm{x}$ & $\mathrm{x}$ & $\mathrm{x}$ \\
\hline
\end{tabular}

9 Strukturování založené na rozlišení kvalit a komponent uplatňujeme také v dalších našich textech vztahujících se ke kvalitě výuky (viz např. Janík, Lokajíčková, \& Janko, 2012).

10 Přítomnost dané kvality či komponenty v tabulkách 1-3 v příslušném modelu značí $\mathrm{x}$. 
Tabulka 3

Dimenze kompetence $k$ učení vymezené prostřednictvím kvalit a komponent

Dimenze

jakožto kvality

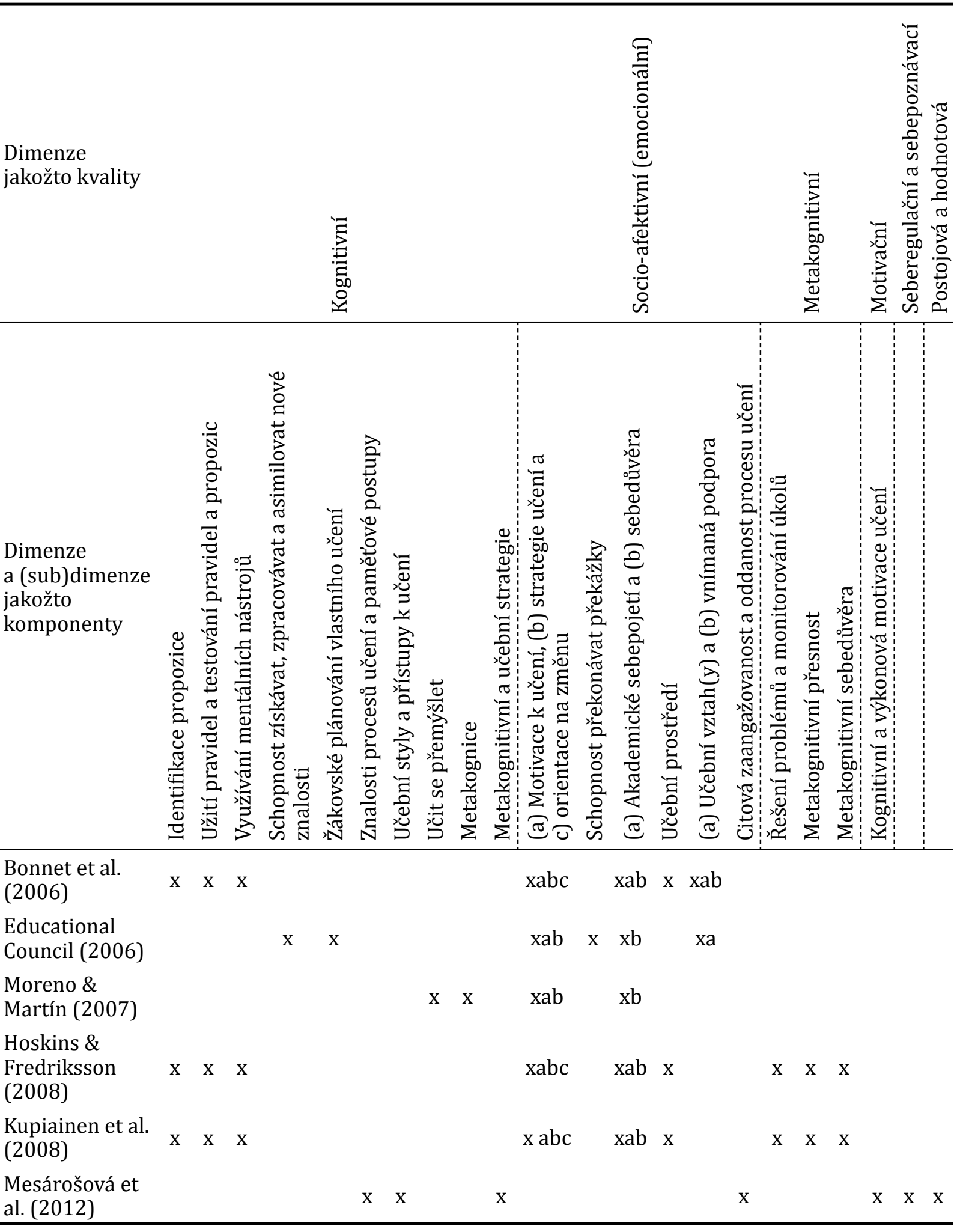


Pro přehlednost jsou v tabulce 2 a 3 rozlišeny dvě hierarchické úrovně dimenze a (sub)dimenze (tzn. dílčí dimenze). $\mathrm{V}$ „kombinovaném“ přístupu (tabulka 3) je možné identifikovat tendence autorů vymezit tři dimenze kompetence $k$ učení, a to dimenzi kognitivní, afektivní (emocionální) a metakognitivní. Některé (sub)dimenze mohou figurovat ve více dimenzích - např. strategie učení je autory řazena bud' pod dimenzi (jako kvalitu) kognitivní nebo afektivní, nebo figurují dokonce samostatně - např. metakognice jako samostatná dimenze (jako komponenta) či (sub)dimenze dimenze kognitivní. Vzhledem k blízkosti některých dimenzí a (sub)dimenzí jakožto komponent, byly některé dimenze a (sub)dimenze v tabulce 3 , at' už na základě doporučení vybraných autorů, nebo našeho uvážení, sloučeny (metakognitivní a učební strategie; motivace učení, strategie učení a orientace na změnu; akademické sebepojetí a sebedůvěra; učební vztahy a vnímaná podpora; citová zaangažovanost a oddanost procesu učení; řešení problému a monitorování úkolu; kognitivní a výkonová motivace učení) ${ }^{11}$. Z tabulek 1,2 a 3 lze vypozorovat, že u všech tři zmíněných prrístupů je klíčová (sub)dimenze motivace $k$ učení (pracují s ní všichni autoři), strategií učení a významný podíl má i (sub)dimenze týkající se sebedůvěry.

V dalším textu se zaměříme na rozvíjení a hodnocení kompetence $k$ učení ve výuce.

\section{Rozvíjení a hodnocení kompetence k učení}

Utváření a rozvíjení kompetencí je proces dlouhodobý, problematický a náročný. Jednotlivé kompetence nestojí vedle sebe izolovaně, naopak se prolínají a jsou nadpředmětové, multifunkční (místy se překrývají) (Rámcový vzdělávací..., 2007). Rozvíjení a hodnocení klíčových kompetencí je učiteli považováno za nejnáročnější kurikulární činnosti, což z pohledu učitelů základních škol naznačil výzkum Monitoring implementace kurikulární reformy (MIKR, 2009) a z pohledu gymnaziálních učitelů výzkum Kvalitní škola (Janík et al., 2010a, s. 93).

Janík et al. (2011, s. 21) se domnívají, že je k rozvíjení klíčových kompetencí nezbytné, aby výuka překročila rámec konkrétního učiva a žák pracoval s nejobecnějšími cílovými úrovněmi obsahu (srov. Westera, 2001, s. 82). Žák sám

11 Přítomnost (sub)dimenzí jakožto komponent, do kterých vybraní autoři zařazují více dílčích komponent, si v některých př́padech vyžádala v tabulce 3 rozlišení označením a, b, c. To proto, že někteří autoři vymezují všechny dílčí části komponent a někteří jen jednu či dvě části. 
by si tak měl být vědom rozvoje svých klíčových kompetencí, měl by se na jejich rozvíjení aktivně podílet a uvědomovat si je ve svých činnostech. Ideální stav představuje rozvíjení kompetencí jako završující etapa k ovládnutí pojmů prostřednictvím činnosti na základě hlubokého porozumění (Janík et al., 2011, s. 24). V zájmu kvality výuky je proto zapotřebí směřovat $\mathrm{k}$ hlubšímu porozumění právě těm konstruktům, které utvářející „novou” kulturu vyučování a učení ${ }^{12}$ - např. podpůrné učební klima, kognitivní aktivizace, transfer, dekontextualizace, metakognice, kompetence a další. Uvedené konstrukty nicméně zatím nejsou patřičně rozpracovány v naší didaktické teorii, a tím je menší šance, že se s nimi prvoplánově setkáme v didaktickém uvažování a jednání učitelů (srov. Knecht et al., 2010). Proto je žádoucí promýšlet cesty směřující k rozvíjení kompetence k učení.

\subsection{Utvář́ení a rozvíjení kompetence k učení}

Chvál, Kasíková a Valenta (2012, s. 13) konstatují, že „záměrné rozvíjení kompetence k učení závisí na kvantitě a kvalitě dostupných př́ležitostí k učení" (angl. opportunities to learn, něm. Gelegenheiten zum Lernen) (srov. Knecht et al., 2010, s. 49). S přihlédnutím k dalším autorům (Seidel \& Prenzel, 2006; Lipowski et al., 2009) mají podle Najvara et al. (2011, s. 91) př́ležitosti k učení povahu určité výzvy, která podněcuje žáky k tomu, aby se zabývali učivem (resp. učebními úlohami). Navenek se projevují v aktivitách učitele i žákủ a je možné je ve výukových situacích pozorovat (srov. Knecht et al., 2010, s. 50).

Janík et al. (2010b, s. 19) v souvislosti s rozvíjením klíčových kompetencí kladou následující požadavky na výukové situace: (1) transfer (dekontextualizaci), (2) zohledňování relevantního situačního kontextu (vytvářet cíleně takové situace, kde se kompetence může projevovat) a (3) provazování určitých typů situací se „skutečným životem”. Aby se do výuky tyto požadavky promítly, je možné zajistit prostřednictvím řešení učebních úloh žáky - tímto způsobem lze kompetenci $k$ učení (stejně jako další kompetence) ve výuce rozvíjet (srov. Klieme et al., 2010, s. 107). Knecht et al. (2010) se domnívají, že se ve výuce spíše objevují učební situace, ve kterých lze identifikovat pouze některou z požadovaných charakteristik. Poukazují na problém, že

12 Jak uvádí Weinert (1997, s. 12), pro „novou” kulturu vyučování a učení je charakteristické „aktivní, konstruktivní, samostatné, motivované a celostní učení; učení bez tlaku na dosahované výsledky, které se odehrává ve společenství učících se jedinců, kteří jsou v přibývající míře nezávislí na vyučujícím - vzdělávají se pro situace každodenního života a jejich prostřednictvím“. 
doposud nebyly definovány indikátory učebních úloh (srov. Slavík, Dytrtová, \& Fulková, 2010; Slavík \& Lukavský, 2012), které by přispívaly k podpoře procesu učení, se zvláštním zřetelem k rozvíjení klíčových kompetencí.

Podle Krykorkové a Volfa (2010, s. 157) rozvoj kompetence $k$ učení představuje záměrné vytváření př́ležitostí se zřetelem na (1) součinnost kognitivní a osobnostně sociální dimenze výuky, (2) úkolové situace, (3) kontext, (4) metakognici a (5) porozumění, predporozumění a neporozumění. Význam kontextu se postupně doceňuje a stává se klíčovou proměnnou v procesu poznání:

zpočátku je v učení zřejmá vázanost žáka na kontext - tzn. na situace, ve kterých poznání probíhá, na jejich vztahy a souvislosti, akcentuje se jejich konkretizace, možnosti aplikace, aktivace vlastních zkušeností apod., později, na vyšší kognitivní úrovni, dochází k řešení úkolových situací, které se vztahují k náročnějším operacím a nejsou závislé tolik na konkrétní realitě nebo konkrétních představách (Krykorková \& Volf, 2010, s. 161).

Specifikace př́ležitostí k rozvíjení kompetence $\mathrm{k}$ učení ve výuce je $\mathrm{z}$ teoretického hlediska problematika prozatím otevřená a značně komplikovaná. Komplikace souvisí s multidimenzionálním konstruktem kompetence k učení s košatostí situací, které se vyskytují ve výuce, kde se jen obtížně od sebe oddělují procesy učení a učení se učení (Black et al., 2006 in Chvál, Kasíková, \& Valenta, 2012, s. 15; Waeytens et al., 2002, s. 306).

\subsection{Nástroje rozvíjení kompetence $k$ učení}

Kompetence $k$ učení je jedním z podstatných cílů (předpokládaných výstupů) vzdělávání a měli bychom se proto zamýšlet nad tím, jak podpořit to, aby byla ve výuce rozvíjena. Proto je nezbytné mít k dispozici přístupy (metody či nástroje), které ji umožní lépe uchopit. Je důležité, aby se učitelé vyznali $\mathrm{v}$ tom, na jaké komponenty a kvality se ve výuce mají v rámci určité kompetence zaměřit, aby ji mohli u žáků cíleně rozvíjet. V odborné literatuře můžeme nalézt řadu přístupů - nástrojů, které mohou učitelům při rozvíjení kompetence k učení napomoci (Chvál, Kasíková, \& Valenta, 2012; Janík et al., 2011; Klíčové kompetence..., 2007; Klíčové kompetence..., 2008). Pro omezený rozsah tohoto textu zde podrobněji představujeme jen prŕstupy domácíi ${ }^{13}$.

13 Zahraničním přístupům by bylo vhodné věnovat pozornost v samostatném textu. Pro představu zde alespoň nastíníme britský nástroj ELLI (Crick, 2007). ELLI (Effective Lifelong Learning Inventory) je evaluační nástroj sloužící k posílení procesu učení. Pracuje na vytváření učebního profilu žáka (jednotlivce) či celé třídy (skupiny) prostřednictvím konceptu schop- 
Při bližší analýze těchto nástrojů z hlediska jejich adresátů a možného použití v praxi můžeme rozlišit dvě jejich kategorie, které při analýze kompetence $k$ učení zohledňují tzv. makroměřítko a mikroměřítko (srov. Leach, Ametller, \& Scott, 2010):

(a) Makroměřítko - jedná se o sledování výukových situací v širší perspektivě, které jsou pozorovatelné v delším časovém horizontu a většinou přesahují rámec běžné vyučovací hodiny (např. měsíc, pololetí nebo školní rok). Dalším kritériem širší perspektivy je osobní zkušenost a intenzivní spolupráce (učitele) se žákem, aby bylo možné objektivně posoudit žákův pokrok v učení (jednorázové pozorování a hloubkový rozhovor se žákem by pravděpodobně nebyl dostačující ${ }^{14}$. Prostřednictvím takových nástrojů lze dle našeho názoru lépe postihnout afektivní stránku kompetence k učení. Nástroje tohoto typu jsou určeny pro učitele. Jeden z nich vznikl ve Výzkumném ústavu pedagogickém (VÚP) jako podpora pro zavádění klíčových kompetencí do škol.

(b) Mikroměřítko - jedná se o detailní analýzy (mikroanalýzy) kratších výukových situací (sekvencí) vyučovací hodiny. Tyto detailnější analýzy poskytují „zaostřenější" pohled na kvalitu výuky. Kritérium osobní znalosti žáka, které bylo zmíněno $v$ případě širší perspektivy, nemusí být nutně naplněno. Tento typ nástroje je určen spíše pro pozorovatele - výzkumníka spolupracujícího s učitelem na zkvalitňování výuky.

Je nutné podotknout, že obě námi vymezené kategorie přístupů jsou pro analýzu kompetence $k$ učení potřebné a užitečné, nebot' kompetence k učení je multidimenzionální konstrukt. Nyní budeme jednotlivé př́ístupy stručně charakterizovat.

nosti učit se (learning power). Tuto schopnost nástroj vymezuje prostřednictvím 7 dimenzí: (a) změna a učení (changing and learning), (b) vzájemná závislost (interdepedence), (c) strategické povědomí (strategic awareness), (d) resilience (resilience), (e) kreativita (creativity), (f) vytváření významu (meaning-making) a (g) kritická zvídavost (critical curiosity). Nástroj ELLI využívá dotazník o 72 položkách, který je vyhodnocován prostřednictvím faktorové analýzy. Profil žáka se pak stává výchozím bodem pro rozhovory se žáky (mentoring conversations), které jsou vedeny zaškolenými tutory. S cílem budování strategie pro rozvoj schopnosti učit se (learning power), a to jak individuálně, tak i v rámci celé třídy.

14 Na požadavek osobní zkušenosti a intenzivní spolupráce se žákem lze usuzovat i z některých výše zmíněných dimenzí a (sub)dimenzí - ne všechny kvality a komponenty by bylo možné objektivně pozorovat a posoudit bez osobní znalosti žáka. 
Ad (a) Hladiny klíčových kompetencí Rámcového vzdělávacího programu pro základní vzdělávání (Klíčové kompetence..., 2007)

Přístup VÚP má vést ke sjednocení představy o výuce ke klíčovým kompetencím. Je pojat jako podrobný návod pro učitele při tvorbě školních vzdělávacích programů a jako návod na to, jak zapojit klíčové kompetence do výuky na základních školách. Pojmenovává jednotlivé úrovně zvládání klíčových kompetencí, kterými musí žáci projít, aby se dostali k výstupní úrovni, kterou RVP ZV žádá v 9. ročníku. Jsou rozlišeny dvě úrovně náročnosti (hladiny) - pro 5. a 9. ročník. Analýza (příručka pracuje s pojmem „rozbalování”) spočívá v popisu konkrétních činností žáků - co musí žáci dělat, nezbytně si zapamatovat nebo jaké musí mít postoje, aby danou část klíčové kompetence rozvíjeli. Činnosti žáků pak mají přispět k nalezení kritérií pro hodnocení klíčových kompetencí.

V prŕíručce, $\mathrm{v}$ níž je ten přístup popsán, jsou tyto kategorie činností kompetence k učení: Metody a způsoby učení; Výuka, Výsledky učení; Práce s informacemi a Propojování a využití vědomostí. Kategorie jsou totožné pro 5. i 9. ročník a liší se svou náročností. Klíčové kompetence jsou v příručce doplněny tzv. ukázkovými lekcemi různého rozsahu, které naznačují propojení obsahu s klíčovými kompetencemi a uvádějí, jak je hodnotit.

Ad (a) Hladiny klíčových kompetencí Rámcového vzdělávacího programu pro gymnázia (Klíčové kompetence..., 2008)

Tento další přístup VÚP je určen pro učitele na gymnáziích a je založen na stejném principu jako nástroj předchozí. Pracuje pouze $s$ jednou hladinou kompetencí, která svou náročností navazuje na hladinu odpovídající 9. ročníku. Kompetence $k$ učení je vymezena prostřednictvím kategorií, které se člení do dílčích činností: Své učení a pracovní činnosti si sám plánuje a organizuje, využívá je jako prostředku pro seberealizaci a osobní rozvoj; Efektivně využívá různé strategie učení k získání a zpracování poznatků a informací, hledá a rozvíjí účinné postupy ve svém učení, reflektuje proces vlastního učení a myšlení; Kriticky pristupuje ke zdrojům informací, informace tvořivě zpracovává a využívá při svém studiu a praxi a Kriticky hodnotí pokrok při dosahování cílů svého učení a práce, přijímá ocenění, radu i kritiku ze strany druhých, z vlastních úspěchu i chyb čerpá poučení pro další práci. Stejně jako v předchozím případě je př́ručka doplněna ukázkovými lekcemi. 
Ad (b) Posuzování rozvoje kompetence $k$ učení ve výuce (Chvál, Kasíková, \& Valenta, 2012)

Posuzovací nástroj je založen na přímém pozorování a vnímá výuku jako příležitost $\mathrm{k}$ tomu, aby žáci byli podněcováni $\mathrm{k}$ dalšímu učení a aby si ve výuce osvojili znalosti, dovednosti, schopnosti a postoje důležité pro motivaci, úspěch a pokrok v učení. Posuzovány jsou situace a charakteristiky výuky, které podporují rozvoj kompetence k učení, ale i ty, v kterých je tato kompetence omezována, blokována. Učitel, který se naučí pozorovat výuku podle určitých aspektů, může (dle názoru autorů) uplatnit tuto dovednost kdykoliv je třeba a výuku tak upravovat ${ }^{15}$. Základem posuzovacího nástroje je pozorovací arch, který byl vyvinut s ohledem na rozvoj kompetence $k$ učení ve výuce. Pohled na výuku je rozdělen do určitých dílčích pohledů (nazvány „situace ve výuce“ a „charakteristiky výuky"), v kterých se mohou vyskytovat př́ležitosti $\mathrm{k}$ rozvoji kompetence $\mathrm{k}$ učení. Vzhledem k tomu, že nástroj posuzuje výuku z hlediska kvantity i kvality, prostřednictvím archu jsou tyto situace dále operacionalizovány (zkonkretizovány, převedeny do pozorovatelných činností) prostřednictvím dvou proměnných: výskytu a zásahu.

Tento nástroj podrobně popisuje následující kategorie, které se dále člení do dílčích podkategorií: (1) situace podporující kompetenci k učení (Zacílení výuky; Úkolové situace nižšího řádu; Úkolové situace vyššího řádu; Podpora výkonu; Žákovská volba; Práce s informačními zdroji; Poskytnutí pomoci žákovi při obtížích; Reflexe učební činnosti; Samostatný časový blok věnovaný přímé práci s rozvojem kompetence k učení), (2) situace tlumící kompetenci $k$ učení (Situace osobnostně ponižující; Situace didakticky nepřijatelné) a (3) souhrnné charakteristiky výuky (Časovost situací; Pozitivní atmosféra; Kontextovost výuky). Každá podkategorie je podrobně popsána prostřednictvím charakteristiky situace a pozorovatelných projevů. Jednotlivé podkategorie jsou pak hodnoceny prostřednictvím škálování.

Ad (b) Osvojování učiva ve vztahu k rozvíjení klíčových kompetencí (Janík et al., 2011)

V prřístupu vytvořeném Institutem výzkumu školního vzdělávání Pedagogické fakulty Masarykovy univerzity je kvalita výuky sledována s ohledem na vztah mezi osvojováním učiva a rozvíjením kompetencí. Je založen na rozboru výukových situací a využívá metodiku AAA - metodologický postup o třech krocích:

15 Tento výzkumný nástroj nabízí také variantu evaluační, která je určena učitelům základních (na druhém stupni) i středních škol (Kasíková \& Žák, 2011). 
(1) Anotace zahrnuje poznatky o pozorované výuce a přináší základní poznatky o rozebíraných výukových situacích (kontext). Anotace spočívá v podchycení tématu výuky, návaznosti obsahu (vazba na probíraný obsah v minulosti), didaktického uchopení obsahu (z pohledu učitele) a popisu činnosti žáků.

(2) Analýza spočívá v rozboru vybraných výukových situací. Její součástí může být kontextový diagram, graficky uchopující základní pojmy. Při analýze je kladen důraz na podrobné podchycení struktury pozorovaných výukových situací, jejích hlavních složek a vztahů, s ohledem na přínos výuky pro žáky.

(3) Alterace spočívá v posouzení kvality výukové situace (kategorizace do 4 typů), návrhu alterace a jejím přezkoumání. Situace jsou nejprve posouzeny dle kvality jako: (1) selhávající, (2) nerozvinutá, (3) podnětná a (4) rozvíjející. Úrovně jsou odlišeny mírou př́nosu pro žáky s ohledem na osvojování učiva ve vztahu k rozvíjení kompetencí a potřebou alterací (kvalitativních změn). Nejvyšší úroveň kvality u situace rozvíjející nevyžadují alterace. Čím je však odhadovaná kvalita výuky nižší, tím je potřeba alterací naléhavější.

Jak uvádějí citovaní autoři, kvalitu výuky z pohledu vztahu mezi osvojováním učiva a rozvíjením kompetencí můžeme sledovat prostřednictvím (a) osvojování základních pojmů nebo dovedností, (b) analýzou a porozuměním obsahu a (c) zobecňováním, aplikací a metakognicí (Janík et al., 2011, s. 110). Kompetence $k$ učení $\mathrm{z}$ našeho pohledu představuje nejvyšší cílovou úroveň, které by mělo být dosaženo prostřednictvím „širokého“ transferu z více dílčích situací při práci žáka s obsahem. Z hlediska potenciálu rozvíjet kompetenci k učení ve výuce může být sledovaným kritériem: (a) nabývání znalostí, (b) konceptualizace, (c) žákovské zkoumání a (d) metakognice, řízení učení a motivace ${ }^{16}$.

V našem vlastním výzkumu prostřednictvím metodiky AAA sledujeme ty př́ležitosti, ve kterých by výukové situace měly přispívat k rozvíjení kompetence k učení, a s ohledem na tuto kompetenci budou navrhovány alterace (Lokajíčková, 2013).

16 Vycházíme z kategorií kompetence $k$ učení, které definuje Rámcový vzdělávací program pro základní vzdělávání (Rámcový vzdělávací..., 2007) a dále je specifikuje příručka Výzkumného ústavu pedagogického (Klíčové kompetence..., 2007). 


\section{Diskuze a závěry}

Na základě výše uvedeného lze shrnout: ke (klíčovým) kompetencím bychom měli přistupovat s jistou dávkou kritiky, ale na druhou stranu také s respektem. Než tyto konstrukty podrobovat výhradně kritice, troufáme si navrhnout, že smysluplnější je propracovat vymezení kompetencí tak, aby (klíčové) kompetence byly pro praxi uchopitelné. Aby to bylo možné, je nutná detailní analýza a vymezení obsahu a struktury tohoto konstruktu („dimenzování"). Je důležité, aby si sami učitelé byli vědomi toho, na jaké činnosti se se žáky mají zaměřit a jaké učební úlohy ve výuce se žáky řešit. A to tím spíše, když různé vyučovací předměty nabízejí různé př́ležitosti k rozvíjení (klíčových) kompetencí (srov. Knecht et al., 2010, s. 51).

V našem textu jsme se zaměřili na konstrukt kompetence $k$ učení. Přestože o učení a vyučování již bylo zjištěno a napsáno mnoho, specifikace příležitostí k rozvíjení kompetence k učení ve výuce je stále otevřená. Naznačili jsme, že práce $\mathrm{s}$ kompetencí $\mathrm{k}$ učení je i $\mathrm{v}$ teoretické rovině značně komplikovaná. Také podrobný rozbor jednotlivých dimenzí, vymezených vybranými autory, potvrdil problematické pojetí kompetence k učení jako multidimenzionálního konstruktu a ukázal na komplikace při pokusech o její uchopení. Lze také předpokládat, že jednotlivé dimenze vymezené teoreticky nebude vždy možné zaznamenat a uchopit $\mathrm{v}$ praxi. Předpokládáme to především $\mathrm{u}$ afektivní dimenze kompetence $\mathrm{k}$ učení a jejích dílčích složek vzhledem k jejich subjektivnímu charakteru (srov. Hoskins \& Crick, 2008, s. 6). I přesto se však ztotožňujeme s přesvědčením Krykorkové (2008), která upozorňuje, že afektivní složku není možné opomenout, protože poznávání je provázeno celou řadou osobnostních a mimokognitivních faktorů.

$\mathrm{V}$ textu také představujeme možné přístupy k rozvíjení kompetence $k$ učení. Je patrné, že činnosti žáků hrají v procesu rozvíjení kompetencí klíčovou roli. A analýza činností žáků je společným znakem všech představených přístupů k rozvíjení kompetencí ve výuce. Předpokládáme, že prostřednictvím této analýzy bude možné identifikovat ty výukové situace, které přispějí k podpoře procesu učení. Avšak i k přístupům, podporujícím rozvíjení (klíčových) kompetencí ve výuce, je vhodné přistupovat „opatrně” a s určitým nadhledem. K tomu formulujeme následující zjištění: Dalo by se očekávat, že učitel, který povede žákovské činnosti ve výuce prostřednictvím doporučení, které představuje první představený přístup (Klíčové kompetence..., 2007), by tak měl ve výuce rozvíjet kompetenci k učení. Přestože by hladiny u tohoto př́i- 
stupu měly vycházet přímo $\mathrm{z}$ definice kompetence $\mathrm{k}$ učení v RVP ZV, při bližší analýze se ukazuje, že některé její části se do hladin nepromítly a naopak jiné jsou zde $\mathrm{v}$ porovnání $\mathrm{s}$ definicí navíc. Je tedy důležité, aby se učitelé při rozvíjení (klíčových) kompetencí neřídili jen radami z příruček, ale aby činnosti ve výuce sami intenzivně promýšleli.

Dva poslední přístupy k rozvíjení a hodnocení kompetence k učení ve výuce (Chvál, Kasíková, \& Valenta, 2012; Janík et al., 2011) vykazují podobné postupy a způsoby rozvíjení a kromě toho umožňují rozvíjení kompetence $\mathrm{k}$ učení ve výuce také hodnotit. U nástroje druhého je však navíc zařazeno navrhování alterací. Alterace ve výuce by měly ideálně vést ke změnám ve způsobu, jakým učitel: (a) tvoří učební úlohy, (b) provází žáky při jejich řešení a (c) poskytuje jim zpětné vazby $\mathrm{k}$ úspěšnému a motivujícímu učení (Janík et al., 2011, s. 110). Tento přístup tedy pracuje $\mathrm{v}$ duchu reflexivní praxe (Korthagen et al., 2011, s. 27). Doufáme, že právě metodika AAA by mohla výrazně přispět k propracování indikátorů učebních úloh, které podporují rozvíjení (klíčových) kompetencí (srov. Slavík, Dytrtová, \& Fulková, 2010; Slavík \& Lukavský, 2012). Ačkoli věříme v potenciál tohoto přístupu, je nutné, abychom jej ve vztahu ke kompetenci k učení dále propracovali a specifikovali dílčí charakteristiky, kterými se tato kompetence ve výuce projevuje. S propracováváním tohoto př́stupu v rovině teoretické i praktické se lze podrobněji seznámit v publikaci Kvalita (ve) vzdělávání: obsahově zaměrený př́stup ke zkoumání a zlepšování výuky (Janík et al., 2013).

Výše jsme představili přehled vztahující se ke konstruktu kompetence $k$ učení a prrístupům k jejímu rozvíjení. V první části textu jsme se zabývali vymezením kompetence k učení v návaznosti na koncept (klíčových) kompetencí. Do roviny kompetence $\mathrm{k}$ učení bývá $\mathrm{v}$ kontextu učení stavěno také učení se učit či celoživotní učení. $\mathrm{V}$ domácí odborné literatuře bývají mnohdy první dva zmíněné konstrukty zaměňovány či ztotožňovány, a proto bylo naší snahou tyto konstrukty rozlišit. Dále jsme se pokusili co nejpřehledněji představit dimenze a (sub)dimenze kompetence $\mathrm{k}$ učení u vybraných autorů. Potvrdilo se, jak složitým konceptem kompetence k učení je a že při její operacionalizaci se autoři často pohybují v různých rovinách, jak je možné názorně vidět $\mathrm{v}$ tabulce 1,2 a 3 . $\mathrm{V}$ průřezovém pohledu jsme $\mathrm{u}$ autorů identifikovali tři přístupy k vymezení kompetence k učení prostřednictvím: (1) kvalit - charakteristik, (2) komponent - složek a (3) propojením kvalit a komponent (kombinovaný př́stup). 
V druhé části textu jsme nastínili čtyři domácí př́istupy, jak kompetenci k učení ve výuce rozvíjet. Společným znakem těchto přístupů je analýza činností žáků, která je pro rozvíjení kompetencí klíčová. První dva představené přístupy (Výzkumného ústavu pedagogického) nahlíží na kompetenci k učení prostřednictvím „širší“ perspektivy (makroměřítko). Další dva přístupy (Chvála a Kasíkové a Institutu výzkumu školního vzdělávání) nahlíží na kompetenci k učení více „zaostřeně“ (mikroměřítko) a umožňují i její hodnocení. Právě rozvíjení a hodnocení kompetence $\mathrm{k}$ učení v reálné výuce by mělo být dalším předmětem našeho odborného zájmu.

\section{Literatura}

Belz, H., \& Siegrist, M. (2001). Klíčové kompetence a jejich rozvíjení: Východiska metody, cvičení a hry. Praha: Portál.

Black, P., McCormick, R., James, M., \& Pedder, D. (2006). Learning how to learn and assessment for learning: A theoretical inquiry. Research Papers in Education, 21(2), 119-132.

Bonnet, G., Svecnik, E., Hautamäki, J., Trosseille, B., Fischer, C., Meijer, J., Grønmo, L. S., Cercadillo, L., Wiren, E., Söderberg, S., James, M., Jakobsen, L. B., Fredriksson, U., \& Hoskins, B. (2006). Final report of the Learning to Learn Expert Group to the European Commission, DG EAC A6. Paris/Brussels/Ispra: Joint Research Centre, European Commission.

Crick, R. D. (2007). Learning how to learn: The dynamic assessment of learning power. The Curriculum Journal, 18(2), 127-134.

Education Council (2006). Recommendation of the European Parliament and the Council of 18 December 2006 on key competences for lifelong learning. Brussels: Official Journal of the European Union.

Fredriksson, U., \& Hoskins, B. (2007). The development of learning to learn in a European context. The Curriculum Journal, 18(2), 135-153.

Hautamäki, J., Arinen, P., Eronen,S., Hautamäki, A., Kupiainen, S., Lindblom, B., Niemivirta, M., Pakaslahti, L., Rantanen, P., \& Scheinin, P. (2002). Assessing learning-to-learn: A framework. Helsinki: Centre for Educational Assessment, Helsinki University.

Hoskins, B., \& Crick, R. D. (2008). Lerning to learn and civic competences: Different currencies or two sides of the same coin? Luxemburg: European Commission.

Hoskins, B., \& Fredriksson, U. (2008). Lerning to learn: What is it and can it be measured? Ispra: European Commission.

Hrabal, V., \& Hrabal, V. (2002). Pedagogickopsychologická diagnostika žáka s úvodem do diagnostické aplikace statistiky. Praha: Karolinum.

Hrbáčková, K. \& kol. (2010). Kognitivní a nonkognitivní determinanty rozvoje autoregulace učení studentů. Brno: Paido.

Chvál, M., Kasíková, H., \& Valenta, J. (2012). Posuzování rozvoje kompetence $k$ učení ve výuce. Praha: Karolinum.

Janík, T., Slavík, J., Mužík, V., Trna, J., Janko, T., Lokajíčková, V., Lukavský, J., ... Zlatníček, P. (2013). Kvalita (ve) vzdělávání: obsahově zaměřený př́stup ke zkoumání a zlepšování výuky. Brno: Munipress (v tisku). 
Janík, T., Janko, T., Knecht, P., Kubiatko, M., Najvar, P., Pavlas, T., Slavík, J., Solnička, D., \& Vlčková, K. (2010a). Kurikulární reforma na gymnáziích: výsledky dotazníkového šetření. Praha: VúP.

Janík, T., Knecht, P., Najvar, P., Pavlas, T., Slavík, J., \& Solnička, D. (2010b). Kurikulární reforma na gymnáziích v rozhovorech s koordinátory pilotních a partnerských škol. Praha: VÚP.

Janík, T., Lokajíčková V., \& Janko, T. (2012). Komponenty a charakteristiky zakládající kvalitu výuky: přehled výzkumných zjištění. Orbis Scholae, 6(1), 27-55.

Janík, T., Slavík, J., Najvar, P., Hajdušková, L., Hesová, A., Lukavský, J., Minaříková, E., Píšová M., \& Švecová, Z. (2011). Kurikulární reforma na gymnáziích od virtuálních hospitací $k$ videostudiím. Praha: VÚP.

Kasíková, H., \& Žák, V. (2011). Učíme děti učit se. Hospitační arch. Praha: Národní ústav pro vzdělávání.

Kaščák, O., \& Pupala, B. (2009). Výchova a vzdělavanie v základných diskurzoch. Prešov: Rokus.

Klieme, E., Maag-Merki, K., \& Hartig, J. (2010). Kompetence a jejich význam ve vzdělávání. Pedagogická orientace, 20(1), 104-119.

Klíčové kompetence v základním vzdělávání (2007). Praha: VÚP.

Klíčové kompetence na gymnáziu (2008). Praha: VÚP.

Knecht, P., Janík, T., Najvar, P., Najvarová, V., \& Vlčková, K. (2010). Příležitosti k rozvíjení kompetence k řešení problémů ve výuce na základních školách. Orbis Scholae, 4(3), 37-62.

Kocourková, ̌̌., \& Pastorová, M. (2011). Pojetí klíčových kompetencí v kurikulech vybraných zemí. Praha: VÚP.

Korthagen, F. A. J., Kessels, J., Koster, B., Lagerwerf, B., \& Wubbels, T. (2011). Jak spojit praxi s teorií: didaktika realistického vzdělávání učitelů. Brno: Paido.

Krámský, D. (2006). Otázka interdisciplinarity a kompetencí ve vzdělávání. Pedagogika, 56(2), 112-118.

Krykorková, H. (2008). Kognitivní svébytnost, teoretická východiska a okolnosti jejího rozvíjení. Pedagogika, 58(2), 140-155.

Krykorková, H., \& Chvál, M. (2001). Motivační předpoklady rozvoje metakognitivních dispozic. Pedagogika, 51(2), 185-196.

Krykorková, H., \& Volf, P. (2010). Psychologie školního učení a připravenost učitele na rozvoj učebních kompetencí. In H. Krykorková \& R. Váňová (Eds.), Učitel v současné škole (s. 155167). Praha: Nakladatelství Karolinum.

Kupiainen, S., Hautamäki, J., \& Rantanen, P. (2008). EU PRE-PILOT on learning to learn. Executive summary. Helsinki: University of Helsinki.

Leach, J., Ametller, J., \& Scott, P. (2010). Establishing and communicating knowledge about teaching and learning scientific content: The role of design briefs. In K. Kortland \& K. Klaassen (Eds.), Designing theory-based teaching-learning sequences for science education (s. 7-23). Utrecht: CDBeta Press.

Lipowsky, F., Rakoczy, K., Drollinger-Vetter, B., Klieme, E., Reusser, K., \& Pauli, C. (2009). Quality of geometry instruction and its short-term impact on students? Understanding of Pythagorean Theorem. Learning and Instruction, 19(6), 527-537.

Lokajíčková, V. (2013). Výuková situace: Teplá a studentá fronta aneb jak rozvíjet kompetenci k učení v zeměpise. In T. Janík, et al., Kvalita (ve) vzdělávání: obsahově zaměřený př́stup ke zkoumání a zlepšování výuky (v tisku). Brno: Munipress.

Mareš, J. (1998). Styly učení žáků a studentů. Praha: Portál. 
Mareš, J., \& Ouhrabka, M. (2007). Dětské interpretace světa a žákovo pojetí učiva. In J. Čáp \& J. Mareš (Eds.), Psychologie pro učitele (s. 411-440). Praha: Portál.

Mesárošová, M., Mesároš, F., \& Mesároš, P. (2012). Klúčové kompetencie vysokoškolských študentov: Učebná kompetencia a jej vztah k verbálnej a matematickej kompetencii. Československá psychologie, 56(2), 106-118.

Monitoring implementace kurikulární reformy (MIKR) 2008 - souhrnná zpráva. (2009). Praha: ÚIV.

Moreno, A., \& Martín, E. (2007). The development of learning to learn in Spain. The Curriculum Journal, 18(2), 175-193.

Najvar, P., Najvarová, V., Janík, T., \& Šebestová, S. (2011). Videostudie v pedagogickém výzkumu. Brno: Paido.

Perrenoud, P. (1997). Construire des compétenced dés l'école. Pratiques et enjeux pédagogiques. Paris: ESF édituer.

Rámcový vzdělávací program pro základní vzdělávání. (2007). Praha: VÚP.

Řezníčková, D. (2006). Rámcový vzdělávací program pro gymnázia z pohledu geografie (1. díl). Geografické rozhledy, 16(2), 19-20.

Seidel, T., \& Prenzel, M. (2006). Stability of teaching patterns in physics instruction: Findings from a video study. Learning and Instruction, 16(3), 228-240.

Skalková, J. (2007). Kategorie cíle, kompetence, jejich vzájemný vztah a význam pro obsah vzdělávání v kontextu současnosti. Orbis Scholae, 1(1), 7-20.

Slavík, J., Dytrtová, K., \& Fulková, M. (2010). Konceptová analýza tvořivých úloh jako nástroj učitelské reflexe. Pedagogika, 60(3-4), 223-241.

Slavík J., \& Lukavský, J. (2012). Hodnocení kvality expresivních tvořivých úloh ve výuce (na př́kladu výtvarné výchovy). Orbis Scholae, 6(3), 77-97.

Stringher, C. (2006). Learning competence: An Italian exploratory research in elementary schools in Learning to learn network meeting report from the second meeting of the network. Ispra: CRELL/JRC.

Štech, S. (2009). Zřetel k učivu a problém dvou modelů kurikula. Pedagogika, 59(2), 105-115.

Trier, P. (2001). 12 Countries contributing to DeSeCo - A summary report [online]. Dostupné z http://www.deseco.admin.ch/bfs/deseco/en/index/05.parsys.1992.downloadList.41429. DownloadFile.tmp/sfsodesecoccpsummaryreport.pdf

Veteška, J., \& Tureckiová, M. (2008). Kompetence ve vzdělávání. Praha: Grada.

Weinert, F. E. (1997). Lernkultur im Wandel. In E. Beck, T. Guldimann, \& M. Zutavern (Hrsg.), Lernkultur im Wandel. Tagungsband der Schweizerischen Gesellschaft für Lehrerinen- und Lehrerbildung und der Schweizerischen Gesellschaft für Bildungsforschung (s. 11-29). St. Gallen: UVK.

Weinert, F. E. (2001). Concept of competence: A conceptual clarification. In S. D. Rychen \& H. Salganik (Eds.), Defining and selecting key competencies (s. 45-64). Seattle: Hogrefe Huber.

Westera, W. (2001). Competences in education: A confusion of tongues. Journal of Curriculum studies, 33(1), 75-88.

Waeytens, K., Lens, W., \& Vandenberghe, R. (2002). Learning to learn: Teachers' conceptions of their supporting role. Learning and Instruction, 12(3), 305-322. 


\title{
Autorka
}

Mgr. Veronika Lokajíčková, Masarykova univerzita, Pedagogická fakulta, Institut výzkumu školního vzdělávání, Poříćí 31, Brno 603 00, email: veronikalokajickova@atlas.cz

\section{Learning competencies and possibilities for their development and evaluation: Defining the concept and a review of current approaches}

\begin{abstract}
This theoretical study aims to provide an overview of knowledge concerning learning competencies and the possibilities for their development during instruction. The study is divided into two parts. The first one is concerned with defining the concept of learning competencies with regards to the concept of (key) competencies. Following selected authors, learning competencies are structured into (sub)dimensions, and so the approach to learning competencies as a multidimensional construct is highlighted. Further on, we point out how particular dimensions and (sub)dimensions are classified by selected authors, which brings further questions regarding this construct. Three approaches to defining learning competencies are identified - definitions according to: (1) qualities - characteristics, (2) components - elements, and (3) combination of qualities and components (combined approach). In the second part of the study, four Czech approaches to developing learning competencies in the instruction are introduced. The first two (of The Research Institute of Education) see learning competencies through the „wide“ perspective (macroscale). The other two (of Chvál and Kasíková and The institute for Research in School Education) see learning competencies more „in focus“ (microscale) and also allow for its evaluation.
\end{abstract}

Keywords: learning competencies, learning to learn, competencies, key competencies, competence development, instructional quality, evaluation

Trna, J. (2012). Jak motivovat žáky ve fyzice se zaměřením na nadané. Brno: Masarykova univerzita a Paido.

Kniha prezentuje výsledky dlouhodobého výzkumu poznávací motivace ve fyzikálním a přírodovědném vzdělávání se zaměřením na nadané žáky. Prezentovaný teoretický, empirický a konstrukční výzkum vede k závěru, že rozvoj žáků významně závisí na jejich motivaci, zejména motivaci poznávací. Jádro knihy tvoří dvě sady poznávacích motivačních výukových technik se zaměřením na nadané žáky. Všechny obsažené poznávací motivační výukové techniky jsou doplněny konkrétními příklady. 